\title{
A novel three-component reaction between isocyanides, alcohols or thiols and elemental sulfur: a mild, catalyst-free approach towards $\boldsymbol{O}$-thiocarbamates and dithiocarbamates
}

\author{
András György Németh, György Miklós Keserű and Péter Ábrányi-Balogh*
}

\author{
Full Research Paper \\ Address: \\ Hungarian Academy of Sciences, Research Centre for Natural \\ Sciences, Institute of Organic Chemistry, Medicinal Chemistry \\ Research Group, 1519 Budapest, POB 286, Hungary \\ Email: \\ Péter Ábrányi-Balogh* - abranyi-balogh.peter@ttk.mta.hu \\ * Corresponding author \\ Keywords: \\ ditihiocarbamate; elemental sulfur; multicomponent reaction; one-pot; \\ thiocarbamate
}

Open Access

\author{
Beilstein J. Org. Chem. 2019, 15, 1523-1533. \\ doi:10.3762/bjoc. 15.155 \\ Received: 19 March 2019 \\ Accepted: 21 June 2019 \\ Published: 10 July 2019 \\ Guest Editor: T. J. J. Müller \\ (C) 2019 Németh et al.; licensee Beilstein-Institut. \\ License and terms: see end of document.
}

This article is part of the thematic issue "Multicomponent reactions III".

\begin{abstract}
A new multicomponent reaction has been developed between isocyanides, sulfur and alcohols or thiols under mild reaction conditions to afford $O$-thiocarbamates and dithiocarbamates in moderate to good yields. The one-pot reaction cascade involves the formation of an isothiocyanate intermediate, thus a catalyst-free synthesis of isothiocyanates, as valuable building blocks from isocyanides and sulfur is proposed, as well. The synthetic procedure suits the demand of a modern organic chemist, as it tolerates a wide range of functional groups, it is atom economic and easily scalable.
\end{abstract}

\section{Introduction}

$O$-Thiocarbamates belong to a class of important biologically active molecules, used mainly as fungicides [1-3] in agricultural and pharmaceutical fields. In particular, recently antitumor [4], anesthetic [5] and enzyme inhibitory effects were discovered, including HIV-1 reverse transcriptase inhibition activity [6-11]. Moreover, their utilization as highly regio- and stereoselective organocatalysts in specific types of chemical tranformations [12-17] was introduced, as well. More recently, $O$-thiocarbamates have been used as $\mathrm{H}_{2} \mathrm{~S}$ donors in biological systems [18] and as intermediates in pharmaceutically significant organic syntheses $[19,20]$. The dithiocarbamate structural moiety can be found in biologically active molecules widely applied as fungicides, herbicides, pesticides [21-25] and in some cases as enzyme inhibitors [26] or antitumor agents [27]. These species are also used as valuable synthetic intermediates [28] and chemosensors for mercury and silver [29,30].

The general methods for the synthesis of $O$-thiocarbamates and dithiocarbamates traditionally rely on substitution reactions of the corresponding halogenated precursors, including thiophosgene [31-33], thiocarbamoyl chlorides [34-37], chlorothionoformates or chlorodithioformates [38-41] providing the appro- 
priate thiocarbamate analogues in good yields (Scheme 1). However, these methods suffer from the formation of toxic, malodorous and/or extremely corrosive byproducts generated by the elimination of the halogen atoms. One should note that the application of these halogenated thiocarbonic acid derivatives might be dangerous and require thorough precaution. Considering dithiocarbamates, a number of methods are based on the reaction of amines and the readily available, but toxic and volatile carbon disulfide [42-45]. Greener methods for the synthesis of thiocarbamates and dithiocarbamates have been developed such as the addition of the amine component to potassium thiocyanate $[46,47]$ or isothiocyanate [48-52] showing better atom economy. Nonetheless, only a few examples can be found in the literature starting from thiocyanates, and regarding the isothiocyanates the preparation of the reagent is required as an additional reaction step before.

The synthesis of isothiocyanates generally relies on the reaction between thiophosgene and amines, thus involves the use of a highly toxic reagent with narrow functional group compatibility [53-56]. Various thiocarbonyl transfer reagents have been developed in the last decades to overcome these drawbacks, such as thiocarbonyl-diimidazole or di-2-pyridyl thionocarbonate [57,58]. Decomposition of dithiocarbamate salts or thiocarbamates with various reagents offers a good alternative [5962] as well, however, this approach first requires the synthesis of the appropriate precursor. Nitrile oxides react with thiourea to afford isothiocyanate and harmless urea [63-65], but one should note that the instability of the nitrile oxides leads to many byproducts, turning this approach less attractive. The synthesis of isothiocyanates starting from isonitriles involves sulfur-containing reagents such as thallium thiocarboxylates or thiols in the presence of radical initiators [66-68]. All the previously reported methods for the synthesis of $O$-thiocarbamates, dithiocarbamates and isothiocyanates start from toxic and/or unstable reagents, generate halogen waste or have narrow functional group tolerance. The bench-stable, environmentally benign, cheap and nontoxic elemental sulfur offers an alternative starting material to integrate sulfur into the product [69]. For a single molecule, Tan and co-workers showed isothiocyanate might be formed from an isocyanide by elemental sulfur in the presence of a base in low yield [70]. In certain cases, sulfur can be trapped by in situ generated carbenes to afford $O$-thiocarbamates [71,72]. Thioureas and $S$-thiocarbamates are also accessible through multicomponent reactions starting from isocyanides and sulfur [73-75]. The cumbersome synthesis of isothiocyanates from isocyanides and sulfur [76] can be enhanced using various catalysts such as selenium, molybdenum, copper, rhodium [77-82] or tellurium [83] providing the isothiocyanates in excellent yields. These approaches on the other hand suffer from the use of heavy metals, toxic chal- thiophosgene<smiles>S=C(Cl)Cl</smiles>

thiocarbamoyl chlorides<smiles>[R]N([R])C(=S)Cl</smiles>

chlorothionoformates, chlorodithioformates<smiles>[R]C(=S)Cl</smiles>
$\stackrel{\mathrm{R}^{1} \mathrm{R}^{2} \mathrm{NH}}{\longrightarrow}$

carbon disulfide

$$
S_{*}=s
$$$$
\stackrel{\mathrm{R}^{1} \mathrm{R}^{2} \mathrm{NH}}{\longrightarrow}
$$

potassium thiocyanate

$$
\begin{aligned}
& \mathrm{K}^{+-} \mathrm{S}-\mathrm{C} \equiv \mathrm{N} \\
& \underset{\text { or } \mathrm{R}^{3} \mathrm{SH}}{\stackrel{\mathrm{R}^{3} \mathrm{OH}}{\longrightarrow}} \\
& \mathrm{H}_{2} \mathrm{~N}^{\mathrm{S}} \mathrm{X}^{-\mathrm{R}^{3}}
\end{aligned}
$$

isothiocyanates

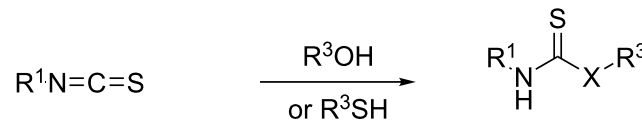

$$
\begin{aligned}
& \mathrm{X}=\mathrm{O}, \mathrm{S}
\end{aligned}
$$

carbene this work

$$
\begin{aligned}
& \mathrm{R}^{1} \mathrm{NC} \\
& \frac{\mathrm{S}_{8}}{\stackrel{\mathrm{R}^{3} \mathrm{OH}}{\text { or } \mathrm{R}^{3} \mathrm{SH}}} \\
& {\underset{H}{H}}_{X=O, S}^{S} X^{-R^{3}}
\end{aligned}
$$

Scheme 1: Synthetic routes to $O$-thiocarbamates and dithiocarbamates.

cogens and/or long reaction times. More recently, a novel threecomponent method has been published starting from readily available amines and sodium bromodifluoracetate [84], but this synthetic route provides halogenated waste, as well. As a continuation of our interest in the development of multicomponent reactions [85-87] and reactions involving sulfur [88], herein, we describe a novel synthesis of $O$-thiocarbamates and dithiocarbamates via a three-component reaction of elemental sulfur, isocyanides and alcohols or thiols (Scheme 1). Moreover, during the investigation of the reaction mechanism, we have identified and improved a catalyst-free method for the preparation of isothiocyanates. 


\section{Results and Discussion}

The model reaction of 2,6-dimethylphenyl isocyanide (1a), elemental sulfur $\left(S_{8}\right)$ and methanol (2a) was employed to screen for the optimal reaction conditions (Table 1). The reactions were followed by TLC and HPLC-MS. Based on preliminary experiments in our laboratory, the reaction was performed in tetrahydrofuran (THF) at $40{ }^{\circ} \mathrm{C}$ for $1 \mathrm{~h}$ using a 1.5 equiv excess of sodium hydride as the base, $\mathrm{S}_{8}$ and the alcohol component (Table 1, entry 1) resulting in the desired thiocarbamate $\mathbf{3 a}$ in $58 \%$ yield. During the purification procedure, the change of the stationary phase for the column chromatography from aluminium oxide to silica, resulted in an increased yield of $72 \%$ (Table 1, entry 2). After the optimization of the purification process, the excess of the reagents and the role of the base were studied. Increasing the molar excess of all reagents to 2 equiv provided 3a in $91 \%$ yield (Table 1, entry 3 ), however, the yield was decreased by the use of a larger excess (Table 1, entry 4). Reducing the amount of the reagents was not helpful (Table 1, entry 5), and one can see that 2.5 equiv of sulfur and methanol did not increase the yields either (Table 1, entry 6). A longer reaction time $(2 \mathrm{~h})$, however, enhanced the product yield from $72 \%$ (Table 1 , entry 2 ) to $84 \%$ (Table 1 , entry 7 ). Thus we have combined this reaction time with the elevated molar excess of the reagents resulting in thiocarbamate 3a in $94 \%$ yield (Table 1, entry 8). The advantageous effect of heating was supported by the decreased yield (72\%) obtained when performing the reaction at ambient temperature (Table 1, entry 9). Next, the effect of different solvents was investigated, showing that acetonitrile $(\mathrm{MeCN})$ and 2-methyltetrahydrofuran (MeTHF) proved to be suitable alternatives to THF (Table 1, entries 13 and 15) that might be advantageous considering the wide application of these solvents in industrial production $[89,90]$. On the contrary, the use of dioxane, methyl tert-butyl ether (MTBE), toluene or dichloromethane (DCM) was unfavorable, providing the thiocarbamate in $67 \%, 29 \%, 12 \%$ and $30 \%$ yields, respectively (Table 1 , entries 10,11, 12, and 14). Notably, in the lack

Table 1: Optimization of the reaction conditions for the synthesis of $O$-thiocarbamates.

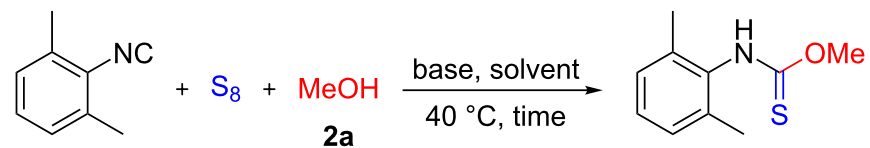

$1 \mathbf{a}$

$3 \mathbf{a}$

\begin{tabular}{|c|c|c|c|c|c|}
\hline Entry & Solvent & Base & Time $[\mathrm{h}]$ & $\begin{array}{l}\text { Molar excess } \\
\mathbf{2 a} / \mathrm{S}_{8} / \text { base }\end{array}$ & Yield [\%] ${ }^{a, b}$ \\
\hline 1 & $\mathrm{NaH}$ & THF & 1 & 1.5:1.5:1.5 & $58^{c}$ \\
\hline 2 & $\mathrm{NaH}$ & THF & 1 & $1.5: 1.5: 1.5$ & 72 \\
\hline 3 & $\mathrm{NaH}$ & THF & 1 & $2: 2: 2$ & 91 \\
\hline 4 & $\mathrm{NaH}$ & THF & 1 & $2.5: 2.5: 2.5$ & $80^{d}$ \\
\hline 5 & $\mathrm{NaH}$ & THF & 1 & $1.5: 1.5: 2$ & 61 \\
\hline 6 & $\mathrm{NaH}$ & THF & 1 & $2.5: 2.5: 2$ & 88 \\
\hline 7 & $\mathrm{NaH}$ & THF & 2 & $1.5: 1.5: 1.5$ & 84 \\
\hline 8 & $\mathrm{NaH}$ & THF & 2 & $2: 2: 2$ & $94^{d}$ \\
\hline 9 & $\mathrm{NaH}$ & THF & 2 & $2: 2: 2$ & $72^{\mathrm{e}}$ \\
\hline 10 & $\mathrm{NaH}$ & dioxane & 2 & $2: 2: 2$ & 67 \\
\hline 11 & $\mathrm{NaH}$ & MTBE & 2 & $2: 2: 2$ & 29 \\
\hline 12 & $\mathrm{NaH}$ & toluene & 2 & $2: 2: 2$ & $12^{d}$ \\
\hline 13 & $\mathrm{NaH}$ & $\mathrm{MeCN}$ & 2 & $2: 2: 2$ & $92^{d}$ \\
\hline 14 & $\mathrm{NaH}$ & $\mathrm{DCM}$ & 2 & $2: 2: 2$ & 30 \\
\hline 15 & $\mathrm{NaH}$ & MeTHF & 2 & $2: 2: 2$ & $87^{d}$ \\
\hline 16 & $\mathrm{NaH}$ & THF & 2 & $2: 2: 2$ & $72^{f}$ \\
\hline 17 & $\mathrm{Cs}_{2} \mathrm{CO}_{3}$ & THF & 2 & $2: 2: 2$ & $0(26)^{g}$ \\
\hline 18 & DIPEA & THF & 2 & $2: 2: 2$ & $0(30)^{g}$ \\
\hline 19 & DBU & THF & 2 & $2: 2: 2$ & 39 \\
\hline 20 & $\mathrm{NaOEt}$ & THF & 2 & $2: 2: 2$ & $0(53)^{g}$ \\
\hline 21 & - & THF & 2 & $2: 2: 2$ & n.r. \\
\hline
\end{tabular}

aReaction conditions: $\mathbf{1 a}(1 \mathrm{mmol}), \mathrm{S}_{8}, \mathbf{2 a}$, base, solvent $(3 \mathrm{~mL})$, time, under argon atmosphere at $40{ }^{\circ} \mathrm{C}$. ${ }^{\mathrm{b}}$ lsolated yields. ${ }^{\mathrm{C}} \mathrm{Flash}$ column chromatography performed on aluminium oxide as stationary phase. ${ }^{\mathrm{d}}$ Average of two runs. ${ }^{e}$ Room temperature. ${ }^{f}$ Lack of inert atmosphere. ${ }^{9}$ Yield of isothiocyanate intermediate. n.r. $=$ no reaction. 
of inert atmosphere, the yield decreased to $72 \%$, and unidentified byproducts were detected that might be explained with the decomposition or side reactions of the isocyanide component under air. In the case of using other bases, such as caesium carbonate $\left(\mathrm{Cs}_{2} \mathrm{CO}_{3}\right)$, diisopropylethylamine (DIPEA) or sodium ethoxide $(\mathrm{NaOEt})$, only the isothiocyanate intermediate of the reaction was isolated (Table 1, entries 17, 18, and 20). However, using diazabicycloundecene (DBU) as the base allowed the formation of the desired product, but only in $39 \%$ yield (Table 1, entry 19). Without any basic additive, no reaction occurred (Table 1, entry 21) and the starting compounds were recovered.

With the optimized reaction conditions in hand, the generality and substrate scope of the reaction using different isocyanides were investigated (Scheme 2). Considering the yield of various aromatic isonitriles, no significant difference was noticed between electron-withdrawing and electron-donating substituents (3c and 3d, respectively). The ortho-iodo-substituted $\mathbf{3 b}$ was obtained in an excellent yield (94\%) demonstrating that no steric hindrance occurs during the reaction. Taking into account aliphatic derivatives, $O$-methyl cyclohexylcarbamothioate (3e) was formed in good yield (82\%), however, $O$-methyl tert-butylcarbamothioate (3f), partly due to the volatile nature of the isocyanide and the thiocarbamate as well, was obtained only in $54 \%$ yield.

In order to further explore the scope of the reaction, different alcohols were tested (Scheme 3). Regarding the compounds $\mathbf{3 g}-\mathbf{i}$ it can be noticed that the yield drops from the primary alcohol towards the tertiary one $(85 \%, 52 \%$ and $45 \%$, respec- tively) that might be attributed either to steric hindrance or the growing instability of the conjugate base of the secondary and tertiary alcohol, respectively. The present method provided the allylic derivative $\mathbf{3 j}$ in $72 \%$ yield, however, applying ethylene glycol resulted in $\mathbf{3 k}$ in $34 \%$ yield only. In the latter case no dimeric product but several unidentified side products were detected by TLC and HPLC-MS. Although the full conversion of the isocyanide to the isothiocyanate intermediate was observed by TLC and HPLC-MS, phenol proved to be unreactive under the standard reaction conditions. Consequently, we have turned our attention to different benzylic alcohols that could be utilized to further examine the functional group tolerance of the reaction. Notably, chlorine, bromine and iodine substituents were compatible with the transformation, providing $\mathbf{3 m}, \mathbf{3 n}, \mathbf{3 r}$ and $3 \mathbf{s}$ in $81-89 \%$ yield. The nitrile derivative $\mathbf{3 p}$ was obtained successfully in $62 \%$ yield, showing the reactivity difference between the cyano and the isocyano groups. Interestingly, methoxy-substituted thiocarbamates $\mathbf{3 o}$ and $\mathbf{3 t}$ were obtained in lower $53 \%$ and $56 \%$ yield, respectively, that decreased further to $34 \%$ in the case of the trimethoxy-substituted product $3 \mathbf{u}$. As the methoxy group is inert under the standard reaction conditions, one might assume that the electron-donating ability reduces the stability of the in situ-generated anion, just as in the case of the secondary and tertiary alcohols. The nitro derivative 3q was isolated in $30 \%$ yield along with multiple byproducts detected that may be due to possible reductive side-reactions caused by sulfur [91]. To the best of our knowledge, out of the 21 synthesized $O$-thiocarbamate derivatives (Scheme 2 and Scheme 3), 18 compounds are new, and only $\mathbf{3 d}, \mathbf{3 e}$ and $\mathbf{3 f}$ are known in the literature [92-94]. The new derivatives have been characterized by ${ }^{1} \mathrm{H}$ NMR, ${ }^{13} \mathrm{C}$ NMR, HRMS and melting

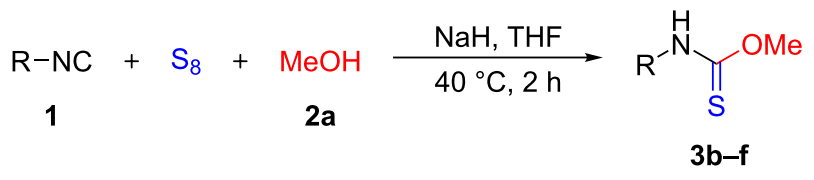<smiles>COC(=S)Nc1ccccc1I</smiles>

3b, $94 \%$<smiles>COC(=S)Nc1ccc(F)cc1</smiles>

$3 c, 65 \%$<smiles>COC(=S)Nc1ccc(OC)cc1</smiles>

3d, $63 \%$<smiles>COC(=S)NC1CCCCC1</smiles>

$3 e, 82 \%$<smiles>COC(=S)NC(C)(C)C</smiles>

3f, $54 \%$ 


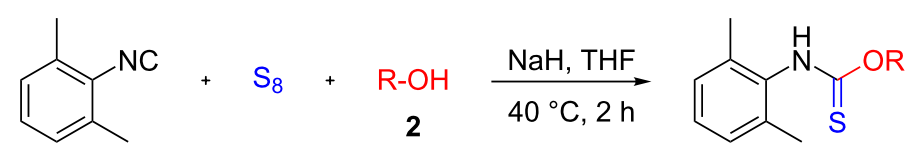<smiles>CCOC(=S)Nc1c(C)cccc1C</smiles>

3g, $85 \%$<smiles>C=CCOC(=S)Nc1c(C)cccc1C</smiles>

3j, $72 \%$<smiles>Cc1cccc(C)c1NC(=S)OCc1ccc(Cl)cc1</smiles>

$3 \mathrm{~m}, 89 \%$<smiles>Cc1cccc(C)c1NC(=S)OCc1ccc(C#N)cc1</smiles>

3p, $62 \%$<smiles>Cc1cccc(C)c1NC(=S)OCc1ccccc1I</smiles>

3s, $81 \%$<smiles>Cc1cccc(C)c1NC(=S)OC(C)C</smiles>

3h, $52 \%$<smiles>Cc1cccc(C)c1NC(=S)OCCO</smiles>

3k, $34 \%$<smiles>Cc1cccc(C)c1NC(=S)OCc1ccc(Br)cc1</smiles>

3n, $81 \%$<smiles>Cc1cccc(C)c1NC(=S)OCc1ccc([N+](=O)[O-])cc1</smiles>

$3 q, 30 \%$<smiles>COc1ccccc1COC(=S)Nc1c(C)cccc1C</smiles>

3t, $56 \%$<smiles>Cc1cccc(C)c1NC(=S)OC(C)(C)C</smiles>

3i, $45 \%$<smiles>Cc1cccc(C)c1NC(=S)OCc1ccccc1</smiles>

3I, $74 \%$<smiles>COc1ccc(COC(=S)Nc2c(C)cccc2C)cc1</smiles>

3o, $53 \%$<smiles>Cc1cccc(C)c1NC(=S)OCc1ccccc1Cl</smiles>

$3 r, 83 \%$<smiles>COc1cc(COC(=S)Nc2c(C)cccc2C)cc(OC)c1OC</smiles>

3u, $34 \%$

Scheme 3: Substrate scope of alcohols. Reaction conditions: $1 \mathrm{a}(1 \mathrm{mmol}), \mathrm{S}_{8}(2 \mathrm{mmol}), 2(2 \mathrm{mmol}), \mathrm{NaH}(2 \mathrm{mmol}), \mathrm{THF}(3 \mathrm{~mL}), 2 \mathrm{~h}$, under argon atmosphere at $40^{\circ} \mathrm{C}$. Yields refer to isolated yields.

point. However, the thiocarbamate $\mathbf{3 c}$ happened to be unstable and started to decompose after work-up. Therefore, an HPLC-MS spectrum of the reaction mixture after completion of the reaction and an HRMS of the crude product are attached in Supporting Information File 1.

Several experiments were performed to discover the reaction conditions that enable the synthesis of $O$-aryl thiocarbamates. Initially, DBU was used in refluxing dioxane, as this base was shown to provide the appropriate aliphatic $O$-thiocarbamate.
However, in this case only the isothiocyanate intermediate was obtained. Then, trimethylamine was applied in refluxing $\mathrm{MeCN}$ [95] or sodium hydroxide in dimethyl sulfoxide (DMSO) at $70{ }^{\circ} \mathrm{C}$. In both cases only the isothiocyanate intermediate and phenol were observed by HPLC-MS but no formation of the desired product.

Then we turned to the synthesis of dithiocarbamate $\mathbf{5 a}$ under the standard reaction conditions, but only the isothiocyanate intermediate was obtained (Table 2 , entry 1 ). Thus a new optimiza- 
Table 2: Optimization of the reaction conditions for the synthesis of dithiocarbamates.

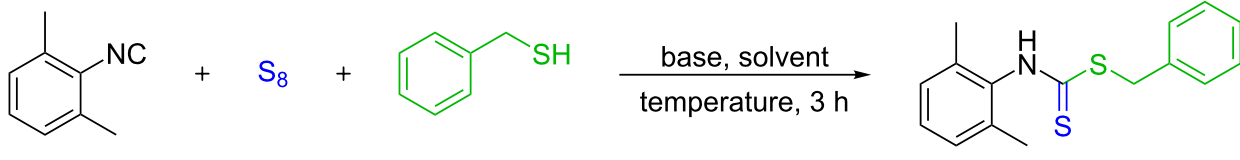

$1 \mathbf{a}$
$4 a$
$5 \mathbf{a}$

\begin{tabular}{|c|c|c|c|c|c|}
\hline Entry & Solvent & Base & Temp. $\left[{ }^{\circ} \mathrm{C}\right]$ & $\begin{array}{l}\text { Molar excess } \\
\mathbf{4 a} / \mathrm{S}_{8} / \text { base }\end{array}$ & Yield $[\%]^{a, b}$ \\
\hline 1 & $\mathrm{NaH}$ & THF & 40 & $2: 2: 2$ & $0^{c}$ \\
\hline 2 & $\mathrm{NaOH}$ & DMSO & 40 & $2: 2: 2$ & 22 \\
\hline 3 & $\mathrm{NaOH}$ & DMSO & 70 & $2: 2: 2$ & 38 \\
\hline 4 & $\mathrm{NaOH}$ & DMSO & 100 & $2: 2: 2$ & 34 \\
\hline 5 & $\mathrm{NaOH}$ & DMSO & 70 & $3: 3: 3$ & 23 \\
\hline 6 & $\mathrm{NaH}$ & DMSO & 70 & $2: 2: 2$ & 36 \\
\hline 7 & $\mathrm{Cs}_{2} \mathrm{CO}_{3}$ & DMSO & 70 & $2: 2: 2$ & 14 \\
\hline 8 & $\mathrm{NaOH}$ & DMF & 70 & $2: 2: 2$ & 43 \\
\hline 9 & $\mathrm{NaOH}$ & DMA & 70 & $2: 2: 2$ & 45 \\
\hline 10 & $\mathrm{NaOH}$ & NMP & 70 & $2: 2: 2$ & 34 \\
\hline 11 & $\mathrm{NaOH}$ & DMA & 70 & $2: 1.2: 2$ & 59 \\
\hline
\end{tabular}

aReaction conditions: $1 \mathrm{a}(1 \mathrm{mmol}), \mathrm{S}_{8}, \mathbf{4 a}$, base, solvent $(3 \mathrm{~mL})$, temperature, $3 \mathrm{~h}$ under argon atmosphere. ${ }^{\mathrm{b}}$ Isolated yield, unless noted otherwise. CIsothiocyanate intermediate detected by HPLC-MS.

tion of the reaction conditions became necessary. Similarly to the previous methodology, the base, the solvent, the temperature and the molar excess of the reagents were changed using the model reaction of 2,6-dimethylphenyl isocyanide (1a), sulfur and benzyl mercaptan (4a, Table 2). Initially, $\mathrm{NaOH}$ was used in DMSO as shown in entry 2 (Table 2), providing the desired dithiocarbamate $\mathbf{5 a}$ in only $22 \%$ yield [96]. In order to improve the yield, firstly the temperature was elevated to $70{ }^{\circ} \mathrm{C}$ and $100{ }^{\circ} \mathrm{C}$ to afford $\mathbf{5 a}$ in $38 \%$ and $34 \%$ yield, respectively (Table 2, entries 3 and 4). Larger excesses of the reagents and the base cut back the yield to $23 \%$ (Table 2, entry 5). Using $\mathrm{NaH}$ instead of $\mathrm{NaOH}$ did not improve the yield of the reaction (Table 2, entry 6), nor did the use of $\mathrm{Cs}_{2} \mathrm{CO}_{3}$ (Table 2, entry 7).
However, using $N, N$-dimethylformamide (DMF) or $N, N$ dimethylacetamide (DMA) as the solvent provided 5a in $43 \%$ and $45 \%$ yield, respectively (Table 2 , entries 8 and 9), while on the other hand, $N$-methyl-2-pyrrolidone (NMP) was disadvantageous for the reaction (Table 2, entry 10). It is well-known that at elevated temperatures sulfur may act as an oxidant, which in this case may have compromised the reaction [97-99]. Therefore, the molar excess of sulfur was decreased, providing a positive effect on the reaction affording $\mathbf{5 a}$ in $59 \%$ yield.

With the optimized reaction conditions in hand, a number of dithiocarbamate derivatives were synthetized (Scheme 4). One might notice the same trend as in the case of thiocarbamates

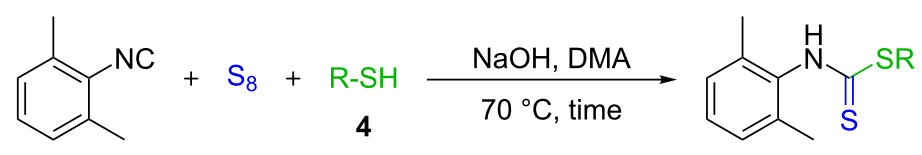

1a<smiles>CCCCCSC(=S)Nc1c(C)cccc1C</smiles>

5b, 3 h, $65 \%$<smiles>Cc1cccc(C)c1NC(=S)SC(C)C</smiles>

5c, $7 \mathrm{~h}, 51 \%$<smiles>Cc1cccc(C)c1NC(=S)SC1CCCCC1</smiles>

5d, 12 h, $47 \%$<smiles>Cc1cccc(C)c1NC(=S)SC(C)(C)C</smiles>

5e, $3 \mathrm{~h}, 22 \%$ 
$\mathbf{3 g - i}$, in particular, the primary mercaptans gave the highest yields (5a and $\mathbf{5 b}$ ), while in the case of secondary (5c and $\mathbf{5 d})$ and tertiary thiols (5e) the products were isolated in lower yields. Although a full conversion of the isocyanide to the isothiocyanate intermediate was observed by TLC and HPLC-MS, thiophenol, likewise to phenol was unreactive under the standard reaction conditions. The generally lower yields, harsher reaction conditions and stronger negative effect of electron-donating groups might be explained with the softer nucleophilicity of the thiols compared to the alcohols [100]. All five dithiocarbamate derivatives synthesized are new and were characterized by ${ }^{1} \mathrm{H}$ NMR, ${ }^{13} \mathrm{C}$ NMR, HRMS and melting point.

After the successful application of various nucleophiles, it was our intention to investigate the scalability of the procedure. Thus, a twenty-fold scale-up of the reaction between the isocyanide 1a, sulfur and methanol (2a) was performed (Scheme 5). In this case, the experimental conditions were necessarily slightly different, as in larger quantities the reaction between the alcohol and $\mathrm{NaH}$ needs to be kept under control. Therefore, the mixture of $\mathbf{1 a}$, methanol and THF was added dropwise to a mixture of $\mathrm{NaH}$ and sulfur in THF under ice-cooling. After the work-up, no chromatography was necessary and the crude product was purified by recrystallization from hexane/ ethyl acetate. The three collected crops of crystals provided the thiocarbamate $3 \mathbf{a}$ in a total of $74 \%$ yield.
We have envisaged that our multicomponent reaction could be compatible with subsequent one-pot transformations. In order to demonstrate this capability, we performed the multicomponent domino annulation between isocyanide 1a, sulfur and methyl anthranilate (6) in DMSO in the presence of $\mathrm{NaOH}$ at $85{ }^{\circ} \mathrm{C}$ that provided 3-(2,6-dimethylphenyl)-2-thioxo-2,3-dihydroquinazolin-4(1H)-one (7), a new quinazolinone derivative in $40 \%$ yield (Scheme 6). Notably, these heterocycles are known for their use as antitumor [101], anticonvulsant [102] or epidermal growth factor receptor tyrosine kinase inhibitory agents [103], JNK inhibitors [104] or 5- $\mathrm{HT}_{3}$ antagonists [105]. Earlier, a one-pot synthesis of an analogous compound was accomplished by Sayahi et al. starting from isothiocyanates in the presence of $\mathrm{CuBr}$ [106].

As aforementioned, in some cases only isothiocyanate $\mathbf{8}$ was detected and/or isolated. Thus, in order to gain mechanistic insights on the generation of $\mathbf{3 a}$, we performed a series of experiments (Scheme 7). As shown in Table 1, isocyanide 1a and sulfur did not react in the absence of a base (Table 1, entry 21). Therefore, the reaction was performed in the presence of $\mathrm{NaH}$ under the standard reaction conditions, providing 8 in $85 \%$ yield (Scheme 7, reaction 1). Notably, the analogous reaction reported by Tan and co-workers using potassium tert-butylate in $t$ - $\mathrm{BuOH} /$ dioxane at $55^{\circ} \mathrm{C}$ for $6 \mathrm{~h}$ resulted in the desired isothiocyanate in only $34 \%$ yield [69]. In the next step, we investi-

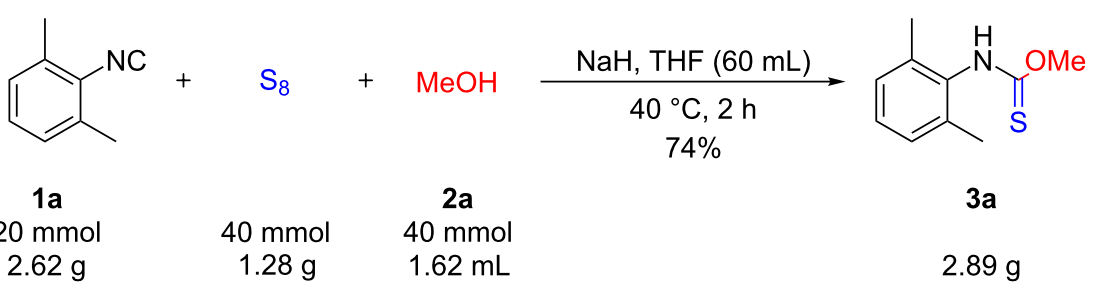

Scheme 5: Scaled-up synthesis for $3 a$

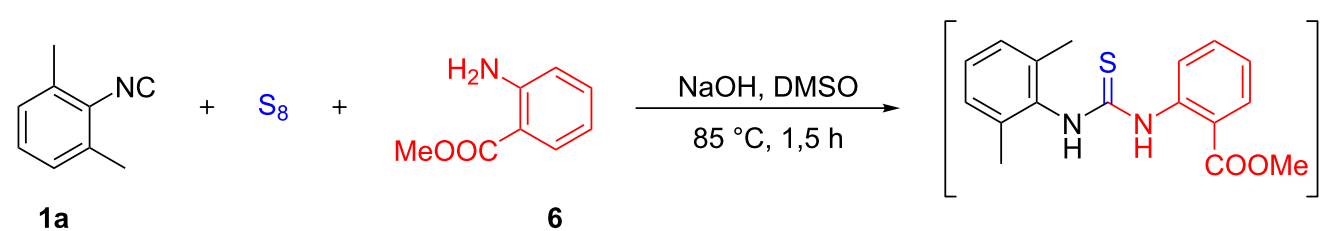<smiles>Cc1cccc(C)c1-n1c(=S)[nH]c2ccccc2c1=O</smiles><smiles>CC(O)[N+](=O)[O-]</smiles>

7, $40 \%$ 
(1)

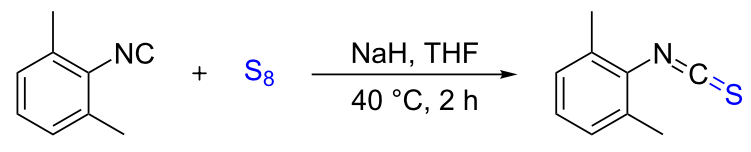

1a

$8,85 \%$

(2)

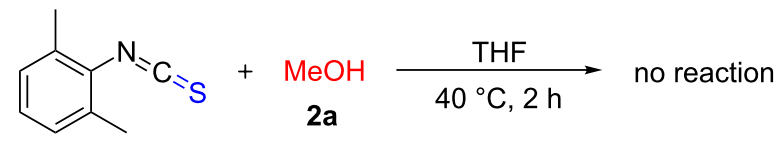

8

(3)

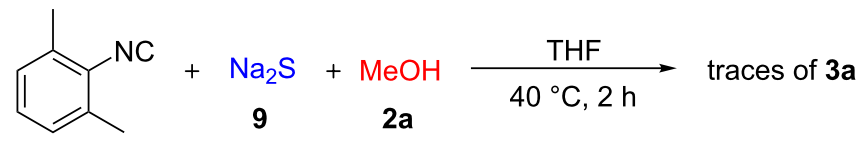

1a

(4)

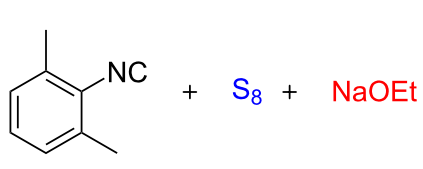

$1 \mathrm{a}$

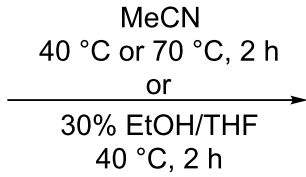

$40{ }^{\circ} \mathrm{C}, 2 \mathrm{~h}$

Scheme 7: Control experiments.

gated the acylation of the alcohol component by the isothiocyanate (Scheme 7, reaction 2). In the absence of a base, no reaction occurred, and consequenctly the base was necessary for both steps of the thiocarbamate formation. This also explains why two equivalents of base were required. Sodium sulfide as the base provided only traces of $\mathbf{3 a}$ suggesting that the activation of sulfur by $\mathrm{NaH}$ produces rather a polysulfide anion instead of sodium sulfide [74,107,108] (Scheme 7, reaction 3). It caught our attention that only isothiocyanate was generated in the presence of NaOEt (Table 1, entry 20). We suspected that THF might not be the best solvent for this base, hence the reaction was performed in $\mathrm{MeCN}$ providing exclusively 8 both at
$40{ }^{\circ} \mathrm{C}$ and $70{ }^{\circ} \mathrm{C}$, and the same result was obtained when a solvent mixture of ethanol and THF was used (Scheme 7 , reaction 4).

Based on the above experimental results and previous reports $[74,107,108]$, a possible reaction mechanism has been proposed (Scheme 8). Initially, the reaction of elemental sulfur and $\mathrm{NaH}$ generates a polysulfide anion that is able to attack the carbenoid carbon atom of isocyanide 1a yielding the isothiocyanate intermediate $\mathbf{8}$. Then, the present nucleophile $(\mathrm{NuH}$, alcohol or thiol) undergoes a nucleophilic addition on $\mathbf{8}$ providing thiocarbamate $\mathbf{3 a}$.

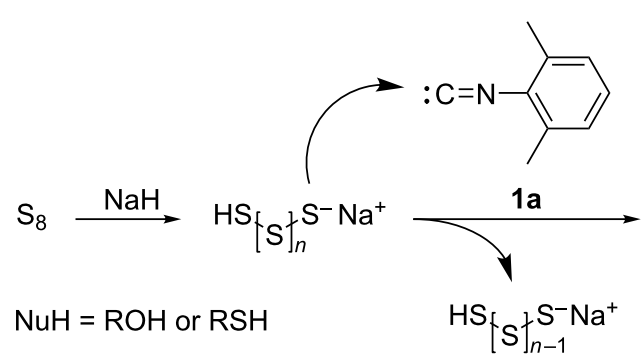

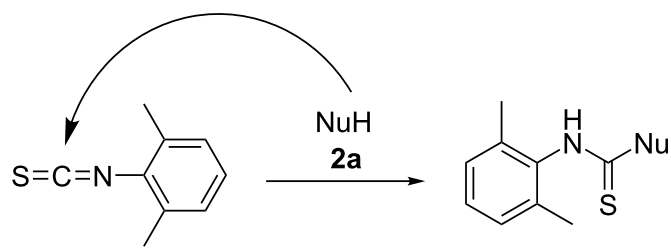

8
$3 a$ 


\section{Conclusion}

In summary, we have developed an efficient, convenient and scalable multicomponent method for the synthesis of $O$-thiocarbamates and dithiocarbamates under mild reaction conditions. This approach includes an improved catalyst-free synthesis of isothiocyanates from elemental sulfur and isocyanides, and shows good functional group tolerance to halogen, olefin and nitrile groups among others. Moreover, this multicomponent reaction is suitable for a one-pot cascade annulation providing a thioxo dihydroquinazolinone derivative in a metal-free approach. Compared to other reported syntheses of thiocarbamates, this method is highlighted by its simplicity, atom economical nature and green operational method. Out of the 29 synthesized compounds, 18 new $O$-thiocarbamates, 5 new dithiocarbamates and 1 new thioxodihydroquinazolinone were characterized.

\section{Supporting Information}

\section{Supporting Information File 1}

Experimental procedures, characterization data and copies of NMR spectra.

[https://www.beilstein-journals.org/bjoc/content/ supplementary/1860-5397-15-155-S1.pdf]

\section{Acknowledgements}

The authors thank Renáta Szabó for her contribution, and Krisztina Németh and Pál Szabó for the HRMS measurements. P. Ábrányi-Balogh was supported by the Hungarian Science Foundation OTKA (PD124598) grant.

\section{ORCID ${ }^{\circledR} \mathrm{iDs}$}

András György Németh - https://orcid.org/0000-0002-3580-4266 György Miklós Keserű - https://orcid.org/0000-0003-1039-7809 Péter Ábrányi-Balogh - https://orcid.org/0000-0002-9284-5160

\section{References}

1. Len, C.; Postel, D.; Ronco, G.; Villa, P.; Goubert, C.; Jeufrault, E.; Mathon, B.; Simon, H. J. Agric. Food Chem. 1997, 45, 3-6. doi:10.1021/jf9607371

2. Zhou, Y.; Wang, L.; Han, L.; Meng, F.; Yang, C. Carbohydr. Res. 2009, 344, 1289-1296. doi:10.1016/j.carres.2009.05.008

3. Ryder, N. S.; Frank, I.; Dupont, M.-C. Antimicrob. Agents Chemother. 1986, 29, 858-860. doi:10.1128/aac.29.5.858

4. Spallarossa, A.; Cesarini, S.; Schenone, S.; Ranise, A Arch. Pharm. (Weinheim, Ger.) 2009, 342, 344-352. doi:10.1002/ardp.200800212

5. Wood, T. F.; Gardner, J. H. J. Am. Chem. Soc. 1941, 63, 2741-2742. doi:10.1021/ja01855a068

6. Lin, G.; Shieh, C.-T.; Ho, H.-C.; Chouhwang, J.-Y.; Lin, W.-Y.; Lu, C.-P. Biochemistry 1999, 38, 9971-9981. doi:10.1021/bi982775e
7. Cesarini, S.; Spallarossa, A.; Ranise, A.; Fossa, P.; La Colla, P.; Sanna, G.; Collu, G.; Loddo, R. Bioorg. Med. Chem. 2008, 16, 4160-4172. doi:10.1016/j.bmc.2007.12.050

8. Cesarini, S.; Spallarossa, A.; Ranise, A.; Bruno, O.; La Colla, P.; Secci, B.; Collu, G.; Loddo, R. Bioorg. Med. Chem. 2008, 16, 4173-4185. doi:10.1016/j.bmc.2007.12.046

9. Spallarossa, A.; Cesarini, S.; Ranise, A.; Bruno, O.; Schenone, S.; La Colla, P.; Collu, G.; Sanna, G.; Secci, B.; Loddo, R. Eur. J. Med. Chem. 2009, 44, 1650-1663. doi:10.1016/j.ejmech.2008.09.024

10. Cichero, E.; Cesarini, S.; Fossa, P.; Spallarossa, A.; Mosti, L. Eur. J. Med. Chem. 2009, 44, 2059-2070. doi:10.1016/j.ejmech.2008.10.014

11. Spallarossa, A.; Cesarini, S.; Ranise, A.; Schenone, S.; Bruno, O.; Borassi, A.; La Colla, P.; Pezzullo, M.; Sanna, G.; Collu, G.; Secci, B.; Loddo, R. Eur. J. Med. Chem. 2009, 44, 2190-2201. doi:10.1016/j.ejmech.2008.10.032

12. Zhou, L.; Tan, C. K.; Jiang, X.; Chen, F.; Yeung, Y.-Y. J. Am. Chem. Soc. 2010, 132, 15474-15476. doi:10.1021/ja1048972

13. Tan, C. K.; Zhou, L.; Yeung, Y.-Y. Org. Lett. 2011, 13, 2738-2741. doi:10.1021/ol200840e

14. Zhou, L.; Chen, J.; Tan, C. K.; Yeung, Y.-Y. J. Am. Chem. Soc. 2011, 133, 9164-9167. doi:10.1021/ja201627h

15. Han, W.-Y.; Li, S.-W.; Wu, Z.-J.; Zhang, X.-M.; Yuan, W.-C. Chem. - Eur. J. 2013, 19, 5551-5556. doi:10.1002/chem.201300206

16. Tan, C. K.; Er, J. C.; Yeung, Y.-Y. Tetrahedron Lett. 2014, 55, 1243-1246. doi:10.1016/j.tetlet.2014.01.009

17. Tay, D. W.; Leung, G. Y. C.; Yeung, Y.-Y. Angew. Chem., Int. Ed. 2014, 53, 5161-5164. doi:10.1002/anie.201310136

18. Steiger, A. K.; Pardue, S.; Kevil, C. G.; Pluth, M. D. J. Am. Chem. Soc. 2016, 138, 7256-7259. doi:10.1021/jacs.6b03780

19. Yoshida, S.; Hayashi, Y.; Obitsu, K.; Nakamura, A.; Kikuchi, T.; Sawada, T.; Kimura, T.; Takahashi, T.; Mukuta, T. Org. Process Res. Dev. 2012, 16, 1818-1826. doi:10.1021/op300237b

20. Yadav, J. S.; Goreti, R.; Pabbaraja, S.; Sridhar, B. Org. Lett. 2013, 15 , 3782-3785. doi:10.1021/ol401760e

21. Heyns, A. Y.; Carter, G. A.; Rothwell, K.; Wain, R. L. Ann. Appl. Biol. 1966, 57, 33-51. doi:10.1111/j.1744-7348.1966.tb06864.x

22. Rafin, C.; Veignie, E.; Sancholle, M.; Postel, D.; Len, C.; Villa, P.; Ronco, G. J. Agric. Food Chem. 2000, 48, 5283-5287. doi:10.1021/jf0003698

23. MacBean, C. The Pesticide Manual, 16th ed.; British Crop Production Council, 2012.

24. Gupta, P. K. Herbicides and fungicides. In Biomarkers in Toxicology; Gupta, R. C., Ed.; Academic Press: Cambridge, MA, USA, 2014; pp 409-431. doi:10.1016/b978-0-12-404630-6.00024-5

25. Thind, T. S.; Hollomon, D. W. Pest Manage. Sci. 2018, 74, 1547-1551. doi:10.1002/ps.4844

26. Carta, F.; Aggarwal, M.; Maresca, A.; Scozzafava, A.; McKenna, R.; Masini, E.; Supuran, C. T. J. Med. Chem. 2012, 55, 1721-1730. doi:10.1021/jm300031j

27. Schwimmer, A.; Rubin, D. Method and compositions for inhibiting tumor cell metabolism. U.S. Patent US5,240,914, Aug 31, 1993.

28. Boas, U.; Gertz, H.; Christensen, J. B.; Heegaard, P. M. H. Tetrahedron Lett. 2004, 45, 269-272. doi:10.1016/j.tetlet.2003.10.182

29. Hatai, J.; Pal, S.; Jose, G. P.; Bandyopadhyay, S. Inorg. Chem. 2012, 51, 10129-10135. doi:10.1021/ic300530f 
30. Konieczna, D. D.; Blanrue, A.; Wilhelm, R. Z. Naturforsch., B: J. Chem. Sci. 2014, 69, 596-604. doi:10.5560/znb.2014-4014

31. Seetharamsingh, B.; Ramesh, R.; Dange, S. S.; Khairnar, P. V.; Singhal, S.; Upadhyay, D.; Veeraraghavan, S.; Viswanadha, S.; Vakkalanka, S.; Reddy, D. S. ACS Med. Chem. Lett. 2015, 6, 1105-1110. doi:10.1021/acsmedchemlett.5b00213

32. Selvakumar, N.; Kumar, G. S.; Malar Azhagan, A.; Govinda Rajulu, G.; Sharma, S.; Kumar, M. S.; Das, J.; Iqbal, J.; Trehan, S. Eur. J. Med. Chem. 2007, 42, 538-543. doi:10.1016/j.ejmech.2006.10.013

33. Sasse, K. Justus Liebigs Ann. Chem. 1970, 735, 158-188. doi:10.1002/jlac. 19707350120

34. Barma, D. K.; Bandyopadhyay, A.; Capdevila, J. H.; Falck, J. R. Org. Lett. 2003, 5, 4755-4757. doi:10.1021/ol0354573

35. Kojima, M.; Nakamura, Y.; Ishikawa, T.; Takeuchi, S. Tetrahedron Lett. 2006, 47, 6309-6314. doi:10.1016/j.tetlet.2006.05.142

36. Iwakawa, T.; Tamura, H.; Murabayashi, A.; Hayase, Y. Chem. Pharm. Bull. 1991, 39, 1939-1943. doi:10.1248/cpb.39.1939

37. Koketsu, M.; Otsuka, T.; Ishihara, H. Phosphorus, Sulfur Silicon Relat. Elem. 2004, 179, 443-448. doi:10.1080/10426500490262612

38. Gromek, S. M.; deMayo, J. A.; Maxwell, A. T.; West, A. M.; Pavlik, C. M.; Zhao, Z.; Li, J.; Wiemer, A. J.; Zweifach, A.; Balunas, M. J. Bioorg. Med. Chem. 2016, 24, 5183-5196. doi:10.1016/j.bmc.2016.08.040

39. Schrader, A. M.; Schroll, A. L.; Barany, G. J. Org. Chem. 2011, 76, 7882-7892. doi:10.1021/j0201329n

40. Boeckman, R. K.; Ge, P.; Reed, J. E. Org. Lett. 2001, 3, 3647-3650. doi:10.1021/ol0165645

41. Steiger, A. K.; Zhao, Y.; Choi, W. J.; Crammond, A.; Tillotson, M. R. Pluth, M. D. Biochem. Pharmacol. 2018, 149, 124-130. doi:10.1016/j.bcp.2017.11.004

42. Ranu, B. C.; Saha, A.; Banerjee, S. Eur. J. Org. Chem. 2008, 519-523. doi:10.1002/ejoc.200700842

43. Safa, K. D.; Tavakkoli Osgoei, S.; Alyari, M. J. Sulfur Chem. 2014, 35, 683-690. doi:10.1080/17415993.2014.953163

44. Halimehjani, A. Z.; Hooshmand, S. E.; Shamiri, E. V. Tetrahedron Lett. 2014, 55, 5454-5457. doi:10.1016/j.tetlet.2014.08.017

45. Halimehjani, A. Z.; Martens, J.; Schlüter, T. Tetrahedron 2016, 72, 3958-3965. doi:10.1016/j.tet.2016.05.025

46. Modarresi-Alam, A. R.; Inaloo, I. D.; Kleinpeter, E. J. Mol. Struct. 2012, 1024, 156-162. doi:10.1016/j.molstruc.2012.05.033

47. Tsuji, K.; Nakamura, K.; Konishi, N.; Okumura, H.; Matsuo, M. Chem. Pharm. Bull. 1992, 40, 2399-2409. doi:10.1248/cpb.40.2399

48. Hagooly, Y.; Gatenyo, J.; Hagooly, A.; Rozen, S. J. Org. Chem. 2009, 74, 8578-8582. doi:10.1021/jo901560b

49. Ranade, S. C.; Hasty, S. J.; Demchenko, A. V. J. Carbohydr. Chem. 2013, 32, 360-379. doi:10.1080/07328303.2013.826670

50. Chniti, I.; Sanhoury, M. A. K.; Chehidi, I. J. Fluorine Chem. 2013, 156, 101-105. doi:10.1016/j.jluchem.2013.09.008

51. Chniti, I.; Sanhoury, M. A. K.; Merlet, D.; Chehidi, I. J. Fluorine Chem. 2014, 168, 223-229. doi:10.1016/j.jluchem.2014.10.015

52. Liu, X.; Wang, Z.; Xie, R.; Tang, P.; Yuan, Q. Eur. J. Med. Chem. 2018, 157, 1526-1540. doi:10.1016/j.ejmech.2018.07.038

53. Wróblewska, A.; Mlostoń, G. Phosphorus, Sulfur Silicon Relat. Elem. 2013, 188, 509-511. doi:10.1080/10426507.2012.736897
54. Zhu, J.-B.; Chen, E. Y.-X. J. Am. Chem. Soc. 2015, 137, 12506-12509. doi:10.1021/jacs.5b08658

55. Bassetto, M.; Ferla, S.; Pertusati, F.; Kandil, S.; Westwell, A. D.; Brancale, A.; McGuigan, C. Eur. J. Med. Chem. 2016, 118, 230-243. doi:10.1016/j.ejmech.2016.04.052

56. Cai, W.; Wu, J.; Liu, W.; Xie, Y.; Liu, Y.; Zhang, S.; Xu, W.; Tang, L.; Wang, J.; Zhao, G. Molecules 2018, 23, No. 252. doi:10.3390/molecules23020252

57. Larsen, C.; Steliou, K.; Harpp, D. N. J. Org. Chem. 1978, 43, 337-339. doi:10.1021/jo00396a035

58. Kim, S.; Yi, K. Y. Tetrahedron Lett. 1985, 26, 1661-1664. doi:10.1016/s0040-4039(00)98578-2

59. Wong, R.; Dolman, S. J. J. Org. Chem. 2007, 72, 3969-3971. doi:10.1021/j0070246n

60. Nath, J.; Ghosh, H.; Yella, R.; Patel, B. K. Eur. J. Org. Chem. 2009, 1849-1851. doi:10.1002/ejoc.200801270

61. Zhang, X.; Lee, Y. K.; Kelley, J. A.; Burke, T. R. J. Org. Chem. 2000, 65, 6237-6240. doi:10.1021/jo000139s

62. Li, Z.-Y.; Ma, H.-Z.; Han, C.; Xi, H.-T.; Meng, Q.; Chen, X.; Sun, X.-Q. Synthesis 2013, 45, 1667-1674. doi:10.1055/s-0033-1338744

63. Jae Nyoung, K.; Ryu, E. K. Tetrahedron Lett. 1993, 34, 8283-8284. doi:10.1016/s0040-4039(00)61411-9

64. Kim, J. N.; Jung, K. S.; Lee, H. J.; Son, J. S. Tetrahedron Lett. 1997, 38, 1597-1598. doi:10.1016/s0040-4039(97)00121-4

65. Baumann, M.; Baxendale, I. R. Beilstein J. Org. Chem. 2013, 9, 1613-1619. doi:10.3762/bjoc.9.184

66. Tanaka, S.; Uemura, S.; Okano, M. Bull. Chem. Soc. Jpn. 1977, 50, 2785-2788. doi:10.1246/bcsj.50.2785

67. Bachi, M. D.; Balanov, A.; Bar-Ner, N. J. Org. Chem. 1994, 59, 7752-7758. doi:10.1021/jo00104a035

68. Bachi, M. D.; Melman, A. J. Org. Chem. 1995, 60, 6242-6244. doi:10.1021/jo00124a056

69. Szabó, T.; Milen, M. Chem. Heterocycl. Compd. 2019, 55, 126-128. doi:10.1007/s10593-019-02427-3

70. Tan, W.; Wei, J.; Jiang, X. Org. Lett. 2017, 19, 2166-2169. doi:10.1021/acs.orglett.7b00819

71. Reiffen, M.; Hoffmann, R. W. Chem. Ber. 1977, 110, 37-48. doi:10.1002/cber.19771100105

72. Cunico, R. F.; Maity, B. C. Org. Lett. 2003, 5, 4947-4949. doi:10.1021/ol030110l

73. Mampuys, P.; Zhu, Y.; Vlaar, T.; Ruijter, E.; Orru, R. V. A.; Maes, B. U. W. Angew. Chem., Int. Ed. 2014, 53, 12849-12854. doi:10.1002/anie.201406717

74. Nguyen, T. B.; Ermolenko, L.; Al-Mourabit, A. Synthesis 2014, 46, 3172-3179. doi:10.1055/s-0034-1379327

75. Pathare, R. S.; Patil, V.; Kaur, H.; Maurya, A. K.; Agnihotri, V. K.; Khan, S.; Devunuri, N.; Sharon, A.; Sawant, D. M. Org. Biomol. Chem. 2018, 16, 8263-8266. doi:10.1039/c8ob01855c

76. Boyer, J. H.; Ramakrishnan, V. T. J. Org. Chem. 1972, 37, 1360-1364. doi:10.1021/jo00974a016

77. Zajdlik, A.; Wang, Z.; Hickey, J. L.; Aman, A.; Schimmer, A. D.; Yudin, A. K. Angew. Chem., Int. Ed. 2013, 52, 8411-8415. doi:10.1002/anie.201302818

78. Adam, W.; Bargon, R. M.; Bosio, S. G.; Schenk, W. A.; Stalke, D. J. Org. Chem. 2002, 67, 7037-7041. doi:10.1021/jo026042i

79. Arisawa, M.; Ashikawa, M.; Suwa, A.; Yamaguchi, M. Tetrahedron Lett. 2005, 46, 1727-1729. doi:10.1016/j.tetlet.2005.01.069

80. Farrell, W. S.; Zavalij, P. Y.; Sita, L. R. Organometallics 2016, 35, 2361-2366. doi:10.1021/acs.organomet.6b00302 
81. Chakrabarty, S.; Choudhary, S.; Doshi, A.; Liu, F.-Q.; Mohan, R.; Ravindra, M. P.; Shah, D.; Yang, X.; Fleming, F. F. Adv. Synth. Catal. 2014, 356, 2135-2196. doi:10.1002/adsc.201400017

82. Boyarskiy, V. P.; Bokach, N. A.; Luzyanin, K. V.; Kukushkin, V. Y. Chem. Rev. 2015, 115, 2698-2779. doi:10.1021/cr500380d

83. Fujiwara, S.-i.; Shin-lke, T.; Okada, K.; Aoki, M.; Kambe, N.; Sonoda, N. Tetrahedron Lett. 1992, 33, 7021-7024. doi:10.1016/s0040-4039(00)60922-x

84. Feng, W.; Zhang, X.-G. Chem. Commun. 2019, 55, 1144-1147. doi:10.1039/c8cc09190k

85. Milen, M.; Ábrányi-Balogh, P.; Dancsó, A.; Frigyes, D.; Pongó, L.; Keglevich, G. Tetrahedron Lett. 2013, 54, 5430-5433. doi:10.1016/j.tetlet.2013.07.145

86. Ábrányi-Balogh, P.; Dancsó, A.; Frigyes, D.; Volk, B.; Keglevich, G.; Milen, M. Tetrahedron 2014, 70, 5711-5719. doi:10.1016/j.tet.2014.06.073

87. Varga, V.; Milen, M.; Ábrányi-Balogh, P. Tetrahedron Lett. 2018, 59, 3683-3689. doi:10.1016/j.tetlet.2018.08.063

88. Milen, M.; Slégel, P.; Keglevich, P.; Keglevich, G.; Simig, G.; Volk, B. Tetrahedron Lett. 2015, 56, 5697-5700. doi:10.1016/j.tetlet.2015.09.007

89. Henderson, R. K.; Jiménez-González, C.; Constable, D. J. C.; Alston, S. R.; Inglis, G. G. A.; Fisher, G.; Sherwood, J.; Binks, S. P.; Curzons, A. D. Green Chem. 2011, 13, 854-862. doi:10.1039/c0gc00918k

90. McConvey, I. F.; Woods, D.; Lewis, M.; Gan, Q.; Nancarrow, P. Org. Process Res. Dev. 2012, 16, 612-624. doi:10.1021/op2003503

91. Niknam, K.; Kiasat, A. R.; Kazemi, F.; Hossieni, A. Phosphorus, Sulfur Silicon Relat. Elem. 2003, 178, 1385-1389. doi:10.1080/10426500307905

92. Burrows, A. A.; Hunter, L. J. Chem. Soc. 1952, 0, 4118-4122. doi:10.1039/jr9520004118

93. Degani, I.; Fochi, R.; Magistris, C. Synthesis 2009, 3807-3818. doi:10.1055/s-0029-1218117

94. L’Abbé, G.; Sorgeloos, D.; Toppet, S.; King, G. S. D.; Van Meerwelt, L. Bull. Soc. Chim. Belg. 1981, 90, 63-74. doi:10.1002/bscb.19810900111

95. Lijuan, M.; Shubai, L.; Lili, S.; Mengqi, W. Method for preparing multi-functional sulfide-bonded collaborative antioxidative stabilizer. Chin. Patent Appl. CN 104529875 A, April 22, 2015.

96. Labib, M. B.; Lamie, P. F. Med. Chem. Res. 2016, 25, 2607-2618. doi:10.1007/s00044-016-1703-y

97. Nguyen, T. B.; Ermolenko, L.; Retailleau, P.; Al-Mourabit, A. Angew. Chem., Int. Ed. 2014, 53, 13808-13812. doi:10.1002/anie.201408397

98. Nguyen, L. A.; Ngo, Q. A.; Retailleau, P.; Nguyen, T. B. Green Chem. 2017, 19, 4289-4293. doi:10.1039/c7gc01825h

99. Nguyen, T. B.; Retailleau, P. Org. Lett. 2017, 19, 3887-3890. doi:10.1021/acs.orglett.7b01775

100.Clayden, J.; Greeves, N.; Warren, S.; Wothers, P. Conjugate addition. Organic Chemistry; Oxford University Press: Oxford, U.K., 2001; pp 227-242.

101.Al-Suwaidan, I. A.; Alanazi, A. M.; Abdel-Aziz, A. A.-M.; Mohamed, M. A.; El-Azab, A. S. Bioorg. Med. Chem. Lett. 2013, 23 , 3935-3941. doi:10.1016/j.bmcl.2013.04.056

102.Jatav, V.; Mishra, P.; Kashaw, S.; Stables, J. P. Eur. J. Med. Chem. 2008, 43, 1945-1954. doi:10.1016/j.ejmech.2007.12.003
103.Smaill, J. B.; Gonzales, A. J.; Spicer, J. A.; Lee, H.; Reed, J. E.; Sexton, K.; Althaus, I. W.; Zhu, T.; Black, S. L.; Blaser, A.; Denny, W. A.; Ellis, P. A.; Fakhoury, S.; Harvey, P. J.; Hook, K.; McCarthy, F. O. J.; Palmer, B. D.; Rivault, F.; Schlosser, K.; Ellis, T.; Thompson, A. M.; Trachet, E.; Winters, R. T.; Tecle, H.; Bridges, A. J. Med. Chem. 2016, 59, 8103-8124. doi:10.1021/acs.jmedchem.6b00883

104. Noble, M. E.; Endicott, J. A.; Johnson, L. N. Science 2004, 303 , 1800-1805. doi:10.1126/science.1095920

105. Asagarasu, A.; Matsui, T.; Hayashi, H.; Tamaoki, S.; Yamauchi, Y.; Minato, K.; Sato, M. J. Med. Chem. 2010, 53, 7549-7563. doi:10.1021/jm1002292

106.Sayahi, M. H.; Saghanezhad, S. J.; Bahadorikhalili, S.; Mahdavi, M. Appl. Organomet. Chem. 2019, 33, e4635. doi:10.1002/aoc.4635

107. Okamoto, K.; Yamamoto, T.; Kanbara, T. Synlett 2007, 2687-2690. doi:10.1055/s-2007-991073

108.Chen, H.-Y.; Peng, W.-T.; Lee, Y.-H.; Chang, Y.-L.; Chen, Y.-J.; Lai, Y.-C.; Jheng, N.-Y.; Chen, H.-Y. Organometallics 2013, 32, 5514-5522. doi:10.1021/om400784w

\section{License and Terms}

This is an Open Access article under the terms of the Creative Commons Attribution License (http://creativecommons.org/licenses/by/4.0). Please note that the reuse, redistribution and reproduction in particular requires that the authors and source are credited.

The license is subject to the Beilstein Journal of Organic Chemistry terms and conditions: (https://www.beilstein-journals.org/bjoc)

The definitive version of this article is the electronic one which can be found at: doi:10.3762/bjoc. 15.155 